\title{
Do Redistributive State Taxes Reduce Inequality?
}

\begin{abstract}
Do income taxes levied at a state or regional level affect the after-tax distribution of income? Or do workers merely move between regions, causing pre-tax wages to adjust? Using the full income tax parameters for all U.S. states from 1977-2002, I create a "simulated tax redistribution index" that captures the mechanical impact of changes in tax policy on the Gini coefficient, but is exogenous to any behavioral response. Analyzing the effect of this redistribution index on inequality, I find that gross wages do not adjust so as to undo the effect of changes in state income taxes. On aggregate, more redistributive state taxes do not substantially affect interstate migration, nor do they reduce per-capita state personal income.
\end{abstract}

\section{INTRODUCTION}

A common contention in the public finance literature is that redistribution should occur primarily at the national level (Musgrave, 1959; Oates, 1972). According to this argument, if state or local governments attempt to impose redistributive income taxes, cross-state mobility will lead to a compensating increase in gross wages for high-skill workers. If full adjustment occurs, then net wages for low-skill and high-skill workers will be unaffected by the rise in redistributivity.

This argument suggests that more redistributive state taxes result in efficiency losses without achieving any net redistribution. If true, it suggests that states should focus on raising revenues in the most efficient manner possible, rather than attempting to redistribute between the rich and the poor. The hypothesis also has implications for labor market mobility within the European Union. Particularly between pairs of neighboring countries with a common language (e.g., France and Belgium; Germany and Austria; Britain and Ireland), a rise in tax redistribution in one country may merely lead to cross-border migration, driving up pre-tax inequality, and leaving post-tax inequality unchanged.

Using data from the 1983 and 1989 U.S. Current Population Survey (CPS), Feldstein and Wrobel (1998) find that when states implement more redistributive income tax systems, wages become more unequal (i.e., wages of high-skill workers rise by enough to offset the higher tax rates). They conclude that this adjustment process is rapid: controlling
National Tax Journal Vol. LXI, No. 1 March 2008 
for the 1989 tax structure, tax rates in 1983 have no effect on gross wages in 1989. This is consistent with Blanchard and Katz (1992), who observe relatively rapid migration out of high unemployment areas in response to adverse demand shocks, with the unemployment rate returning to normal after a period of five to seven years.

Others, however, have found more modest effects. Focusing on the top end of the income distribution, and using annual tabulations of estate tax returns from 1965-1998, Bakija and Slemrod (2004) conclude that higher state sales taxes and inheritance/estate taxes have modest but significant negative impacts on the number of federal estate tax returns filed in a state. The rich do flee from higher state taxes, but the resulting deadweight loss is small relative to the revenue raised. This is consistent with Conway and Houtenville (2001) who use migration data from the 1990 Census to investigate the migration patterns of those aged 65 and over. They find that although the elderly are attracted to states with lower personal income and inheritance/estate taxes, the magnitude of the effect is small, and the results are sensitive to the particular specification chosen. ${ }^{1}$

Similarly, studies of welfare and the Earned Income Tax Credit (EITC) have not observed substantial effects at the lower end of the distribution. Cushing-Daniels (2004) uses the 1968-2002 Panel Study of Income Dynamics to study the impact of welfare generosity on mobility, and finds that benefits do not have a significant effect on cross-state migration. Leigh (2004) uses the 1989-2002 CPS to explore the impact of state EITCs on earnings, and concludes that only a small portion of the observed effect could have been due to workers moving into states with more generous EITCs.

From a theoretical standpoint, the extent to which the pre-tax wage distribution will adjust to offset the effect of redistributive taxes depends on the degree to which workers are willing to change location in response to taxes. As Mirrlees (1982) has shown, the optimal amount of redistribution by a particular jurisdiction is a declining function of the degree of mobility in response to taxes. This is generally interpreted to mean that there should be more redistribution at the national level than at the state level, and more redistribution at the state level than at the local level. But whether migration can entirely offset the redistributive effects of taxation at any particular level is ultimately an empirical question.

Since the sharpest empirical predictions about the effect of redistributive taxes on inequality relate to the distribution of hourly wages, this paper, therefore, focuses on hourly wage inequality. For expositional simplicity, I will often refer to this just as "inequality." ${ }^{2}$ To assess the impact of redistributive taxes on gross earnings, I use the National Bureau of Economic Research's Taxsim program (Feenberg and Coutts, 1993) to create a measure of the redistributive effect of personal income taxes across U.S. states over the years 1977-2002. Separately calculating inequality from the March CPS over those same years, I find that more redistributive taxes are not offset by a rise in pre-tax inequality. Analyzing mobility,

Although the effect of taxes on wage inequality is determined at the margin, it is worth noting that in 1990, the middle year of the data range covered by this paper, 67 percent of native-born Americans lived in their state of birth (Census Bureau, 1994).

2 From a social welfare perspective, the income distribution measure that is most commonly utilized is the post-tax distribution of income across families or households, adjusted for household size. That measure will be affected by hourly wage inequality, but also by differences in labor supply and non-labor income, by whether the household is single-headed or partnered (and the extent of assortative matching in the latter case), and by the number of children in the household. 
I do not find clear evidence that more redistributive taxes affect the volume or composition of interstate migration.

The remainder of this paper is structured as follows. The second section analyzes the impact of redistributive taxes on inequality, using a standard measure of the redistributive effect of taxation, and presents a number of robustness checks on this specification. The third section proposes a new class of tax redistributivity measures, based on the S-Gini, and uses these measures to see whether the effect of taxes on gross wages has a stronger effect on the top or bottom of the distribution. The fourth section studies the effect of redistributive taxes on migration, post-tax inequality, and incomes. The fifth section delves into the political economy of redistributive taxation, and the sixth section concludes.

\section{HOW DO REDISTRIBUTIVE TAXES AFFECT THE PRE-TAX GINI COEFFICIENT?}

To test the impact of redistributive taxation on inequality, Feldstein and Wrobel (1998) regress an individual's gross hourly wage on his or her average tax rate, using data from 1983 and 1989. Since the average tax rate is endogenous to hourly earnings, they instrument for the actual average tax rate with a predicted average tax rate, based on demographic characteristics.

A more reduced form approach, which will be implemented here, is to regress a measure of the distribution of hourly wages on a measure of tax redistribution, controlling for state and year fixed effects, and for certain time-varying state characteristics. If it is the case that more redistributive taxes raise the pre-tax hourly wages of high-skilled workers relative to low-skilled workers, there should be a positive relationship between redistributive taxes and hourly wage inequality.

Data are drawn from the March CPS, covering earnings in the years 1977-2002.
Using these surveys, the redistributive effect of taxation and hourly wage inequality are separately estimated for each state and year. Over this relatively long time period, it is also possible to estimate different lag specifications, taking account of the possibility that it may take some time before the wage distribution fully adjusts to changes in taxation.

What is the appropriate measure of the redistributive effect of taxation? For simplicity, I adapt the Reynolds-Smolensky index (Reynolds and Smolensky, 1977), which simply measures the amount by which taxation changes the Gini coefficient for hourly wages. In its usual definition, the Reynolds-Smolensky index $(R S)$ is the difference between the Gini coefficient for after-tax earnings $(G A)$ and the Gini coefficient for before-tax earnings $(G B)$, such that $R S=G A-G B$. To obtain a measure that is increasing with the redistributive effect, I swap the terms to obtain the index $G B-G A$. Using a measure of the redistributive effect of taxation that is based on the Gini coefficient makes it natural to measure hourly wage inequality using the Gini. In the third section, I explore the robustness of these results to the use of alternative measures of inequality.

The redistributive effect of taxation is different from the progressivity of taxes. The redistributive effect is a function of three parameters: the average tax rate, tax progressivity (the disproportionality of tax payments), and the re-ranking effect (which occurs when the tax system takes account of non-income differences). The three measures are discussed and related to one another in Creedy (1999). For the purposes of considering the impact that taxes have on the distribution of wages, what matters is the redistributive effect, since this fully encapsulates the effect of the tax system on the distribution of incomes, regardless of whether that effect is due to changes in the average tax rate, progressivity, or re-ranking. 
Redistributive taxes will potentially affect inequality via two channels. First, because taxes typically take a larger income share of the rich than the poor, tax policies will have a "mechanical" effect on inequality. Second, redistributive taxes may engender a behavioral response, for example, by prompting changes in labor supply or affecting residential choices. In measuring the effect of tax policies on behavior, it is important to form an index of redistribution that measures only the mechanical policy effect of a tax, uncontaminated by any behavioral response. To do this, I calculate the redistributive effect of taxation based not upon the actual after-tax Gini and before-tax Gini in a given state and year, but based on the effect of the taxation system in every state and year on one single sample of households, drawn from the March 1990 CPS. (The March 1990 CPS was chosen on the basis that it is the midpoint of the period 1977-2002, but drawing a sample from another year makes no substantial difference to the results.) This "simulated redistribution index" reflects the mechanical policy impact of the taxation system, but not any behavioral changes that are induced by a more or less redistributive tax system. More details may be found in the Data Appendix.

The measure of redistribution used here accounts only for personal income taxes. While I control for sales taxes and the top rate of inheritance/estate taxes, I do not estimate their redistributive effect (and I do not control for other taxes, such as property taxes). To the extent that the redistributive effect of personal income taxes is positively correlated with the redistributive effect of other taxes, mine will be an underestimate of the true effect. To the extent that the redistributive effect of personal income taxes is negatively correlated with the redistributive effect of other taxes, mine will be an overestimate. However, it is somewhat reassuring to note that Feldstein and Wrobel (1998) found that omitting the redistributive effect of sales taxes made only a slight difference to their estimates.

Both the redistributive effect of taxation and inequality are calculated from the distribution of hourly wages among adults aged $16-55$ with positive earnings. ${ }^{3}$ The mean of the pre-tax Gini coefficient for the distribution of hourly wages is 0.36 with a standard deviation of 0.018 . Within a state, the largest one-year movements observed in the data are -5 Gini points and +6 Gini points. At the 10th and 90th percentiles, the one-year movements are -2 and +2 Gini points respectively. Summary statistics are presented in Appendix Table 1.

On average, the mechanical effect of income taxes was to reduce the Gini coefficient by 0.024 (i.e., by 2.4 Gini points), with a standard deviation of 0.003 . However, this standard deviation overstates the extent of within-state variation in the redistributive effect of taxation. Focusing only on one-year within-state changes, the largest increase and decrease observed in the data are -0.4 and +0.4 Gini points. The changes at the 10th and 90th percentiles are -0.2 Gini points and +0.1 Gini points respectively.

Figure 1 shows a scatter plot of pre-tax hourly wage Gini coefficients for the 50 states and the District of Columbia over the period 1977-2002. The steady upwards trend accords with the well-recognized rise in wage inequality over this period (see for example Autor, Katz, and Kear-

Since the focus here is on hourly wages, there is less reason to be concerned about teenagers biasing the results than if the dependent variable was family income inequality. Nonetheless, the results are not significantly affected if the sample is restricted to those aged 25-55. 
Figure 1. Pre-Tax Hourly Wage Inequality by State 1977-2002

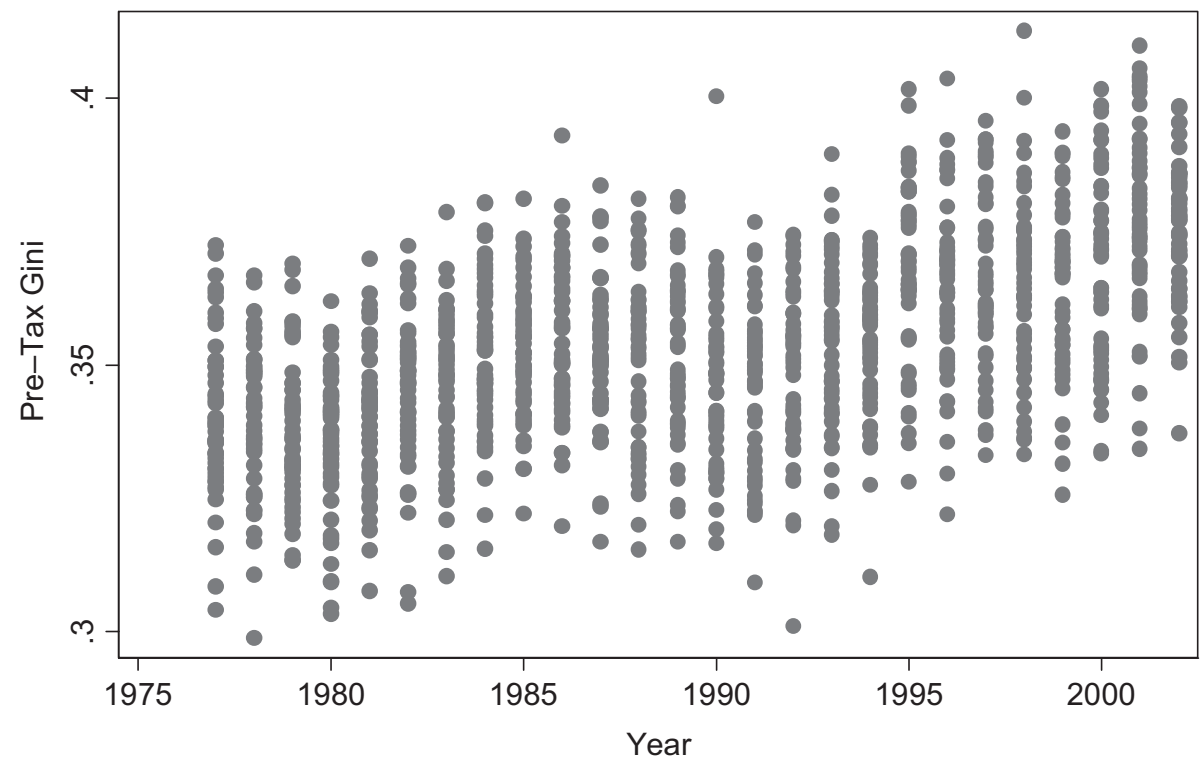

Source: Author's calculations, from March Current Population Surveys.

ney, 2008). ${ }^{4}$ Figure 2 depicts a scatter plot of the redistributive effect of taxation. Taxes became more redistributive in the late-1970s, less redistributive in the 1980s (due to the federal Tax Reform Act of 1986 (TRA86), followed by reductions in redistributivity in some states), and slightly more redistributive again in the 1990s.

To get some sense of the within-state relationship between taxes and inequality, Figure 3 plots hourly wage inequality against the tax redistribution measure for the four most populous states in the United States: California, Florida, New York, and Texas. There are two reasons for choosing these states. First, they constitute a significant fraction of the U.S. population (around 30 percent). Second, using large states reduces the measurement error in estimating inequality using the CPS. It is difficult from this graph to discern any strong positive relationship between redistributivity and pre-tax inequality. The largest rises in hourly wage inequality have occurred in California and New York; in both cases these have taken place at a time when tax redistributivity was either falling or stable.

Clearly, national trends dominate the four graphs. Since the empirical specification will include year fixed effects, Figure 4 shows the results for the same four states, but this time with inequality and redistributivity expressed as the

\footnotetext{
4 Note that the measure of inequality here is based purely on earnings. Since the CPS does not contain information on fringe benefits, it is conceivable that employers may respond to changes in taxation by shifting remuneration from earnings into fringe benefits. To the extent that the redistributive effect of taxes and the propensity of employers to remunerate high-skill workers through fringe benefits are positively correlated, mine will be an underestimate of the effect of redistributive taxes on inequality.
} 
Figure 2. Redistributive Effect of Taxes by State 1977-2002

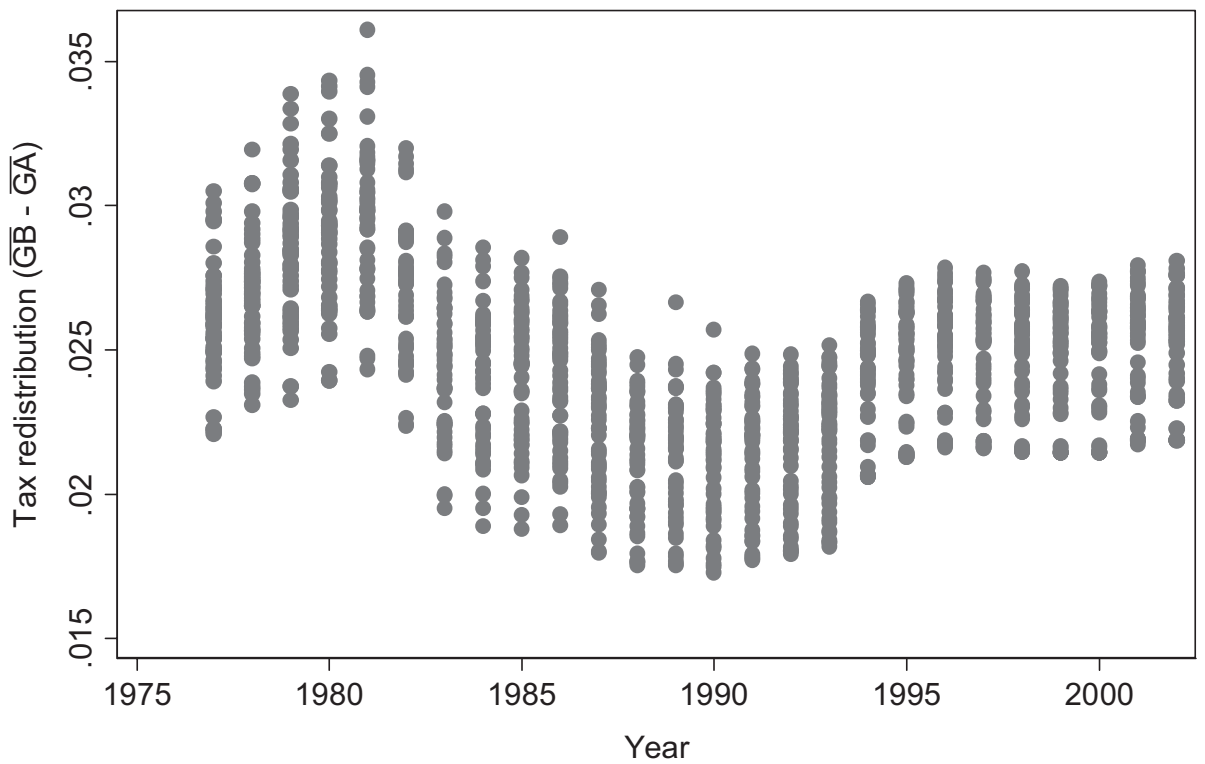

Source: Author's calculations, from March Current Population Surveys and Taxsim model.

Figure 3. Pre-Tax Hourly Wage Inequality (solid line, left axis) and Tax Redistributivity (dashed line, right axis)
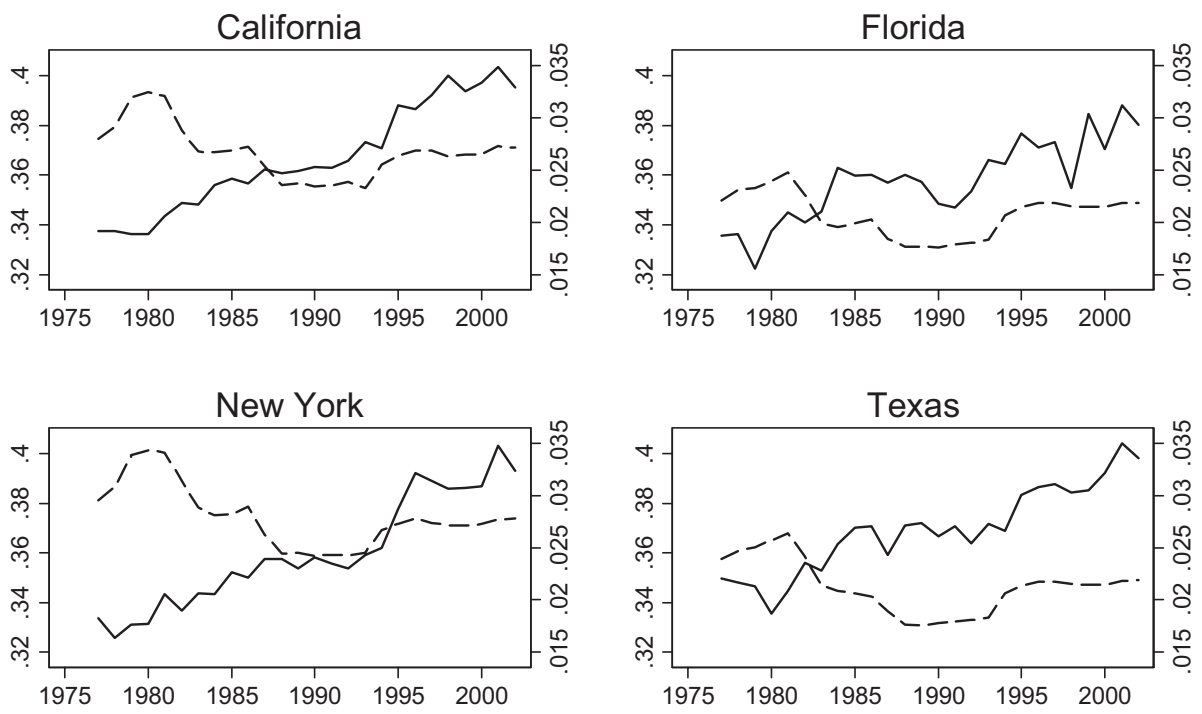

Source: Author's calculations, from March Current Population Surveys and Taxsim model. 
Figure 4. Pre-Tax Hourly Wage Inequality (solid line, left axis) and Tax Redistributivity (dashed line, right axis) (both measured as deviation from annual average)
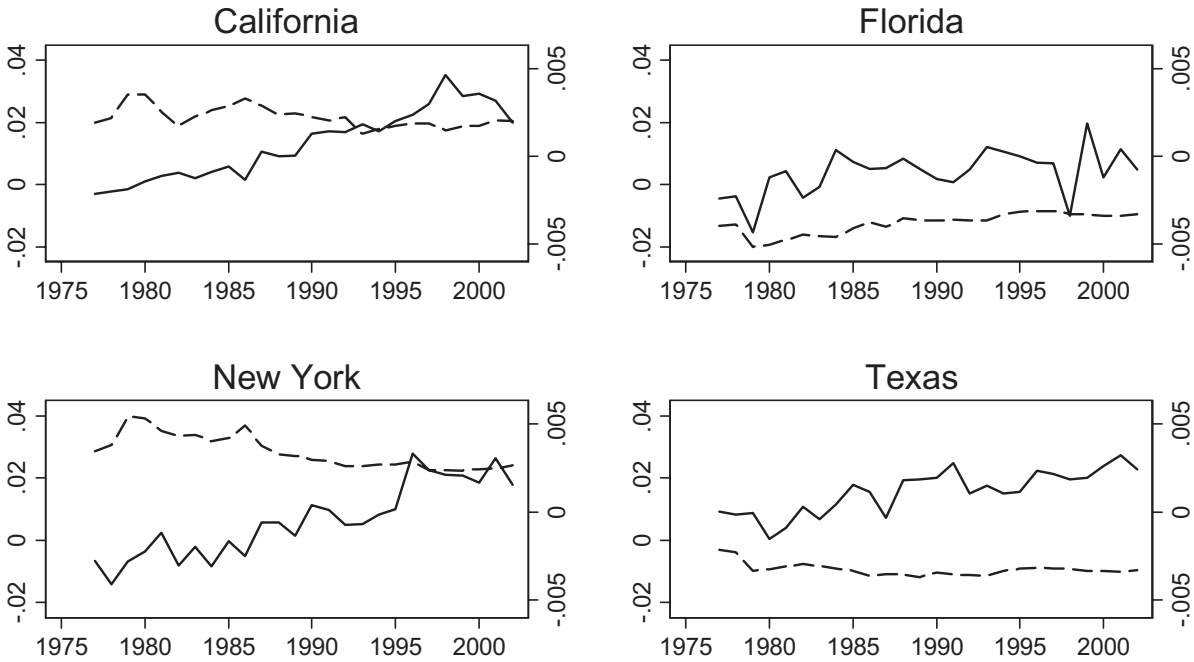

Source: Author's calculations, from March Current Population Surveys and Taxsim model.

deviation from the (unweighted) state average. Again, there does not appear to be any positive relationship between inequality and redistributivity in any of these states.

To test the relationship between taxes and inequality empirically across states, I use panel data from all 50 states and the District of Columbia over the period 1977-2002, and estimate the following equation.

$$
\begin{aligned}
& G B_{s t}=\alpha+\beta(\overline{G B}-\overline{G A})_{s t}+Z_{s t}+\zeta_{s} \\
& +\lambda_{t}+T_{r}+\varepsilon_{s t}
\end{aligned}
$$

In equation [1], $(\overline{G B}-\overline{G A})$ is the amount by which taxation mechanically reduces the Gini coefficient, $G B$ is the Gini coefficient for before-tax inequality, $Z$ are time-varying state characteristics, $\zeta$ is a vector of state dummies, $\lambda$ is a vector of year fixed effects, and $T$ is a region-specific linear time trend.

Note that the year dummies remove most of the impact of changes in federal income taxes, leaving the effects of state income taxes. ${ }^{5}$ This approach is preferable to estimating the redistributive effect of state taxes alone, since it allows for interaction between state and federal taxes. State fixed effects take account of time-invariant factors that may be correlated with both the dependent variable and the key independent variable, such as residents' taste for inequality or redistributive taxation. Including a linear time trend for each of the four Census regions (Midwest, Northeast, South, and West), allows for the possibility that long-run linear changes in a particular part of the United States-perhaps due to changing industrial composition-might have affected both inequality and taxation

5 The year fixed effects do not perfectly purge the data of the effects of changes in federal tax rates, since state and federal income taxes interact through deductibility rules. 
systems. The vector $Z$ includes three other state taxes that might be correlated with state income taxes: the sales tax rate, the maximum state inheritance or estate tax rate, and an indicator for whether the state has an estate tax. It also includes three variables that might affect wage inequality: the unemployment rate, the log of real per capita personal income, and the unionization rate. (Below, I show that the results are robust to excluding these controls.) Standard errors are clustered at the state level, allowing for an arbitrary covariance structure over time within each state (Bertrand, Duflo, and Mullainathan, 2004).

The coefficient on $\beta$ can be interpreted as follows.

- $\beta=0$ : more redistributive taxes have no impact on the pre-tax distribution of income.

- $\quad \beta<0$ : more redistributive taxes not only have a mechanical effect of equalizing the wage distribution, but also lead the pre-tax wage distribution to become more equal.

- $0<\beta<1$ : a tax system that has the mechanical effect of reducing the Gini by one point leads to a compensating increase in the pre-tax distribution of income of less than one Gini point, partly attenuating the equalizing effects of the tax change.

- $\beta=1$ : a tax system that has the mechanical effect of reducing the Gini by one point leads to a compensating one Gini point increase in the pre-tax distribution of income, with the net result being that the post-tax distribution of wages remains unaffected by the redistributive effects of the tax.

- $\quad \beta>1$ : the pre-tax wage distribution overcompensates for the effect of more redistributive taxes, with the result that more redistributive taxes cause the post-tax wage distribution to become more unequal.

Although it is possible to come up with explanations as to why $\beta$ might be less than zero or greater than one, the main focus of the theoretical literature has been over whether $\beta$ is closer to zero or to one. ${ }^{6}$ The empirical analysis below will, therefore, focus on the question of whether $\beta$ is closer to zero or to one. By ignoring the hypotheses with less theoretical support $(\beta<0$ and $\beta>1)$, it is possible to construct a clearer "horserace" between the two most plausible explanations: that wages adjust to fully offset tax changes, or that wages do not adjust to offset tax changes.

It is possible that taxes may affect wages only with some lag. If this is the case, then simply regressing current inequality on current redistributivity may miss part of the adjustment process. Therefore I experiment with adding up to six lagged terms to the model. In the case of six lags, I estimate the equation

$$
\text { [2] } \begin{aligned}
& G B_{s t}=\alpha+\beta 1(\overline{G B}-\overline{G A})_{s t} \\
+ & \beta 2(\overline{G B}-\overline{G A})_{s t-1}+\ldots+\beta 7(\overline{G B}-\overline{G A})_{s t-6} \\
+ & Z_{s t}+\zeta_{s}+\lambda_{t}+T_{r}+\varepsilon_{s t} .
\end{aligned}
$$

The six-year limit is necessarily arbitrary, but is chosen on the basis that it is the lag length used by Feldstein and Wrobel (1998), who analyze the period

\footnotetext{
Two plausible explanations for $\beta<0$ are that states with more redistributive taxes use the additional revenue to create jobs for low-skilled workers, or that the inflow of low-skill workers leads to the formation of a union which raises the wages of all low-skilled workers. A possible explanation for $\beta>1$ is that more redistributive taxes lead to an economic slump, which harms low-wage workers more than high-wage workers. In addition, either result could occur if tax redistribution is endogenous with respect to some other policy that affects wage inequality, and is not controlled for in the regressions.
} 
1983-1989. Since tax rates are only available from 1977 onwards, all regressions are restricted to cover the same period, that is, 1983-2002. ${ }^{7}$

One might imagine several different processes through which taxes affect the distribution of wages. Wage inequality might be affected only by the current tax system, only by a previous year's tax system, or by some combination of the two. To take in account of these various possibilities, I present both current and lagged coefficients. In addition, I estimate the linear sum of the lagged redistributivity coefficients, and the linear sum of all redistributivity coefficients. ${ }^{8}$ I then present a one-tailed F-test against the null hypothesis that the sum of the coefficients is equal to or smaller than zero (which would imply that the wage distribution does not become more unequal in response to more redistributive taxes), and a one-tailed F-test against the null hypothesis that the sum of the coefficients is equal to or greater than one (which would imply that the wage distribution fully adjusts in response to taxes).

The rationale for using one-tailed F-tests, rather than the standard twotailed tests, is that the policy outcome of interest is whether the coefficient on tax redistributivity is closer to zero or one; not whether it is precisely zero or precisely one. Any coefficient above one would mean that a rise in tax redistributivity was more than compensated for by a rise in wage inequality. Likewise, a coefficient below zero would mean that a rise in tax redistributivity led to an additional fall in wage inequality. These findings carry the same policy implications as if the coefficient had been-respectively-precisely one or precisely zero.

These null hypotheses are calculated for current taxes, lagged taxes, and both current and lagged taxes. Thus a reader whose prior was that taxes affected wage inequality immediately would focus only on the "Current taxes" F-tests, while a reader whose prior was that taxes affected wage inequality only with some lag would focus on the "Lagged taxes" F-tests. A reader who originally thought that the effect was some combination of current and lagged taxes would focus on the "Current and lagged taxes" F-tests.

Table 1 shows the results of these specifications. With between zero and six lags, the coefficient on the contemporaneous tax rate is negative, and the linear sum of the lags is always negative. The hypothesis that wage inequality does not rise in response to a rise in tax redistributivity cannot be rejected in any specification. ${ }^{9}$

7 For the specification in which wage inequality is regressed on current taxes, the results are similar if the sample is broken into the pre-TRA86 period (1983-1985) and the post-TRA86 period (1987-2002).

8 The linear sum is estimated using the lincom command in Stata. Roger Newson describes the calculation of the standard error on a linear sum as follows: If $b$ is the vector of coefficients, $V$ is the covariance matrix of $b$, and $a$ is a vector defining the linear combination, then the standard error of the linear combination is calculated as $\left(a^{\prime} V a\right)^{0.5}$. So the standard error of the average of $n$ coefficients is $1 / n^{*}\left(a^{\prime} V a\right)^{0.5}$.

9 It is important to note that the F-tests in Table 1 relate to current taxes, the sum of lagged taxes, and the sum of current and lagged tax rates. This is not the same as an F-test on the joint significance of the lags, which is a test of whether any of the lags are significantly different from zero (or from one). The rationale for focusing on the sum of the lags is that from a policy perspective, what matters most is the aggregate effect of tax redistribution on wage inequality, rather than whether redistribution causes inequality to fluctuate. However, the results are substantively unchanged if the hypothesis testing is based on joint significance testing instead of testing the sum of the coefficients. The hypothesis that none of the coefficients are different from zero cannot be rejected in the first two specifications in Table 1. The hypothesis that none of the coefficients are different from zero can be rejected (at the five percent level) in the third and fourth specifications of Table 1, but this is solely due to the fourth lag of tax redistribution, which has a negative coefficient, not a positive coefficient. The hypothesis that none of the coefficients are different from one can be rejected for all specifications in Table 1 . Overall, the joint F-tests suggest that more redistributive taxes may cause inequality to fluctuate downwards (after a four-year lag), but they provide no evidence of a positive relationship between tax redistributivity 
TABLE 1

HOW DO REDISTRIBUTIVE TAXES AFFECT THE DISTRIBUTION OF INCOME?

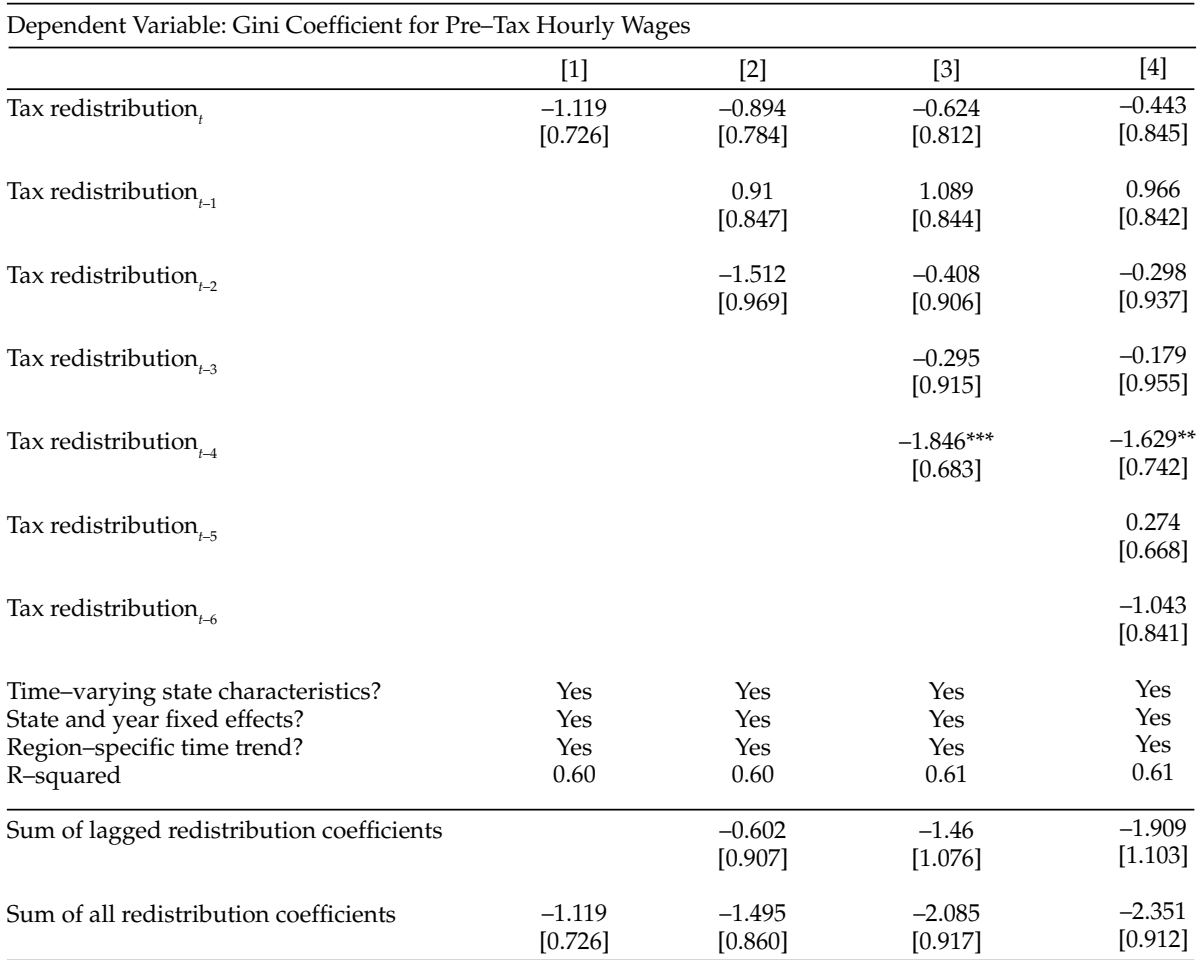

One-Tailed F-test: H0 Is That Tax Redistribution Coefficients $\leq 0$

Can We Reject the Null That Pre-Tax Inequality Is Unaffected by...

\begin{tabular}{lllll} 
Current taxes? & No & No & No & No \\
The sum of lagged taxes? & - & No & No & No \\
The sum of current and lagged tax rates? & No & No & No & No \\
\hline
\end{tabular}

One-Tailed F-Test: H0 Is That Tax Redistribution Coefficients $\geq 1$

Can We Reject the Null That Pre-Tax Inequality Fully Adjusts in Response to...

\begin{tabular}{lcccc} 
Current taxes? & Yes & Yes & Yes & Yes \\
& {$[\mathrm{P}<0.01]$} & {$[\mathrm{P}=0.01]$} & {$[\mathrm{P}=0.03]$} & {$[\mathrm{P}=0.04]$} \\
The sum of lagged taxes? & - & Yes & Yes & Yes \\
& & {$[\mathrm{P}=0.04]$} & {$[\mathrm{P}=0.01]$} & {$[\mathrm{P}<0.01]$} \\
The sum of current and lagged tax rates? & Yes & Yes & Yes & Yes \\
& {$[\mathrm{P}<0.01]$} & {$[\mathrm{P}<0.01]$} & {$[\mathrm{P}<0.01]$} & {$[\mathrm{P}<0.01]$} \\
\hline
\end{tabular}

Note: Robust standard errors, clustered at the state level, in brackets. ${ }^{*},{ }^{* *}$ and, ${ }^{* * *}$ denote statistical significance at the $10 \%, 5 \%$, and $1 \%$ levels, respectively. "Tax Redistribution" is the negative of the Reynolds-Smolensky index, calculated as $\overline{G B}-\overline{G A}$ (see text for details). Time-varying state characteristics are log real personal income per capita, the unemployment rate, the unionization rate, the sales tax rate, the maximum estate/inheritance tax rate, and an indicator for whether the state has an estate tax. Sample is restricted to inequality observations from 1983-2002. Sample size for all specifications is 1,020. 
By contrast, the null hypothesis that pre-tax inequality fully adjusts in response to taxes can be rejected in all 11 specifications, indicating that the main conclusion is not sensitive to the particular lag structure or form of the null hypothesis. This provides strong evidence that the effect of more redistributive state taxes is not undone by a subsequent rise in pre-tax inequality. This result is at odds with Feldstein and Wrobel (1998), who find-using individual-level data from 1983 and 1989-that gross wages fully adjust to changes in taxes within six years.

As Table 1 demonstrates, these results are not particularly sensitive to the number of lags of the tax redistribution variable that are included in the regression. Table 2 also presents four additional robustness checks. The first check omits the time-varying state controls, as a way of testing whether the previous results are sensitive to these controls. The second check weights states by their 2002 population, to account for the fact that wage inequality will typically be better measured in larger states, since there are more CPS observations for these states. The third check omits state fixed effects, and estimates the model using pooled ordinary least squares (OLS) (though still including year fixed effects, since these absorb most changes in federal taxes). And the fourth check estimates the model with random state effects, rather than fixed state effects.

None of these robustness checks seems to have a substantial impact on the main results. As in Table 1, none of the F-tests in Table 2 reject the hypothesis that (in sum) pre-tax inequality is unaffected by tax redistributivity, while they do tend to reject the hypothesis that wage inequality fully adjusts to a change in the level of tax redistribution. The exceptions are in columns 3 and 4: the hypothesis of full adjustment in response to the current tax rate cannot be rejected in the specifications without state effects, or with random state effects. I do not place much weight on these results, however, since a Hausman test strongly rejects the hypothesis that the random effects estimator is consistent, suggesting that the fixed effects results should be preferred..$^{10}$ Overall, the results in Table 2 provide further reassurance that the results are not driven by some idiosyncratic feature of the primary specification.

\section{HOW DO REDISTRIBUTIVE TAXES AFFECT THE TOP AND BOTTOM OF THE INCOME DISTRIBUTION?}

While the results in the previous section suggest that more redistributive taxes do not cause the distribution of gross wages to fully adjust, it is possible that a stronger impact is felt by tax reforms that affect either the bottom or top of the distribution. This could occur if either the poor or the rich were particularly sensitive to tax changes. A straightforward way to test this is to use a measure of income distribution that places more weight on one or other of the ends of the distribution. A natural choice is the S-Gini (Donaldson and Weymark, 1980), a scale-free index that allows for a flexible inequality aversion parameter, $\delta$, which determines the social weight to be applied to parts of the distribution.

The area under the Lorenz Curve, $L(p)$, represents the proportion of total income going to the bottom fraction $p$ of a population with individual income $y$ and mean income $\mu$. If the cumulative density func-

and inequality in any period. An alternative approach would be to test for Granger causality, which requires including a lagged dependent variable, and omitting the current tax redistribution variable; in other words, modifying equation [2] by replacing $(\overline{G B}-\overline{G A})_{s t}$ with $G B_{s t-1}$. Estimating this model produces qualitatively similar results.

10 To take account of the fact that standard errors are clustered at the state level, the Hausman test is estimated using the overid command (Schaffer and Stillman, 2006). 
TABLE 2

ROBUSTNESS CHECKS

\begin{tabular}{|c|c|c|c|c|}
\hline \multicolumn{5}{|c|}{ Dependent Variable: Gini Coefficient for Pre-Tax Hourly Wages } \\
\hline & $\begin{array}{c}1] \\
\text { No State } \\
\text { Characteristics }\end{array}$ & $\begin{array}{c}{[2]} \\
\text { Population } \\
\text { Weighted } \\
\end{array}$ & $\begin{array}{c}3] \\
\text { No State } \\
\text { Effects } \\
\end{array}$ & $\begin{array}{c}{[4]} \\
\text { Random State } \\
\text { Effects } \\
\end{array}$ \\
\hline Tax redistribution $_{t}$ & $\begin{array}{c}-0.738 \\
{[0.909]}\end{array}$ & $\begin{array}{c}-1.612^{*} \\
{[0.905]}\end{array}$ & $\begin{array}{c}0.234 \\
{[1.152]}\end{array}$ & $\begin{array}{l}-0.053 \\
{[0.884]}\end{array}$ \\
\hline Tax redistribution ${ }_{t-1}$ & $\begin{array}{c}0.915 \\
{[0.824]}\end{array}$ & $\begin{array}{c}1.332 \\
{[1.035]}\end{array}$ & $\begin{array}{c}1.038 \\
{[0.840]}\end{array}$ & $\begin{array}{c}1.021 \\
{[0.817]}\end{array}$ \\
\hline Tax redistribution $_{t-2}$ & $\begin{array}{c}-0.39 \\
{[0.956]}\end{array}$ & $\begin{array}{c}0.353 \\
{[0.803]}\end{array}$ & $\begin{array}{c}0.125 \\
{[0.982]}\end{array}$ & $\begin{array}{c}-0.1 \\
{[0.916]}\end{array}$ \\
\hline Tax redistribution $_{t-3}$ & $\begin{array}{l}-0.206 \\
{[0.922]}\end{array}$ & $\begin{array}{c}-0.021 \\
{[0.820]}\end{array}$ & $\begin{array}{c}-0.32 \\
{[1.023]}\end{array}$ & $\begin{array}{c}-0.19 \\
{[0.943]}\end{array}$ \\
\hline Tax redistribution ${ }_{t-4}$ & $\begin{array}{c}-1.611^{* *} \\
{[0.759]}\end{array}$ & $\begin{array}{c}-1.594^{*} \\
{[0.809]}\end{array}$ & $\begin{array}{c}-1.142 \\
{[0.795]}\end{array}$ & $\begin{array}{c}-1.410^{*} \\
{[0.745]}\end{array}$ \\
\hline Tax redistribution ${ }_{t-5}$ & $\begin{array}{c}0.32 \\
{[0.639]}\end{array}$ & $\begin{array}{c}-0.402 \\
{[0.631]}\end{array}$ & $\begin{array}{c}0.612 \\
{[0.688]}\end{array}$ & $\begin{array}{c}0.399 \\
{[0.673]}\end{array}$ \\
\hline Tax redistribution $_{t-6}$ & $\begin{array}{c}-0.89 \\
{[0.821]}\end{array}$ & $\begin{array}{l}-0.687 \\
{[0.635]}\end{array}$ & $\begin{array}{c}-0.47 \\
{[0.869]}\end{array}$ & $\begin{array}{l}-0.694 \\
{[0.792]}\end{array}$ \\
\hline $\begin{array}{l}\text { Time-varying state characteristics? } \\
\text { State effects? } \\
\text { Year fixed effects? } \\
\text { Region-specific time trend? } \\
\text { R-squared } \\
\text { Hausman test } \\
\text { H0: RE is consistent }\end{array}$ & $\begin{array}{c}\text { No } \\
\text { Fixed } \\
\text { Yes } \\
\text { Yes } \\
0.60\end{array}$ & $\begin{array}{c}\text { Yes } \\
\text { Fixed } \\
\text { Yes } \\
\text { Yes } \\
0.76\end{array}$ & $\begin{array}{c}\text { Yes } \\
\text { None } \\
\text { Yes } \\
\text { Yes } \\
0.37\end{array}$ & $\begin{array}{l}\text { Yes } \\
\text { Random } \\
\text { Yes } \\
\text { Yes } \\
0.44 \\
1183.593 \\
\mathrm{P}<0.01\end{array}$ \\
\hline Sum of lagged redistribution coefficients & $\begin{array}{c}-1.862 \\
{[1.146]}\end{array}$ & $\begin{array}{l}-1.020 \\
{[1.094]}\end{array}$ & $\begin{array}{c}-0.157 \\
{[1.129]}\end{array}$ & $\begin{array}{l}-0.974 \\
{[0.987]}\end{array}$ \\
\hline Sum of all redistribution coefficients & $\begin{array}{l}-2.600 \\
{[0.796]}\end{array}$ & $\begin{array}{l}-2.632 \\
{[0.844]}\end{array}$ & $\begin{array}{c}0.077 \\
{[0.560]}\end{array}$ & $\begin{array}{l}-1.027 \\
{[0.568]}\end{array}$ \\
\hline
\end{tabular}

One-Tailed F-test: H0 Is That Tax Redistribution Coefficients $\leq 0$

Can We Reject the Null That Pre-Tax Inequality Is Unaffected by...

\begin{tabular}{lllll} 
Current taxes? & No & No & No & No \\
The sum of lagged taxes? & - & No & No & No \\
The sum of current and lagged tax rates? & No & No & No & No \\
\hline
\end{tabular}

One-Tailed F-Test: H0 Is That Tax Redistribution Coefficients $\geq 1$

Can We Reject the Null That Pre-Tax Inequality Fully Adjusts in Response to...

$\begin{array}{lcccc}\text { Current taxes? } & \text { Yes } & \text { Yes } & \text { No } & \text { No } \\ \text { The sum of lagged taxes? } & {[\mathrm{P}=0.03]} & {[\mathrm{P}<0.01]} & & \text { Yes } \\ & {[\mathrm{P}=0.01]} & {[\mathrm{P}=0.04]} & \text { No } & {[\mathrm{P}=0.02]} \\ \text { The sum of current and lagged tax rates? } & \text { Yes } & \text { Yes } & \text { Yes } & \text { Yes } \\ & {[\mathrm{P}<0.01]} & {[\mathrm{P}<0.01]} & {[\mathrm{P}=0.05]} & {[\mathrm{P}<0.01]}\end{array}$

Note: Robust standard errors, clustered at the state level, in brackets. ${ }^{*},{ }^{* *}$, and ${ }^{* * *}$ denote statistical significance at the $10 \%, 5 \%$, and $1 \%$ levels, respectively. "Tax Redistribution" is the negative of the Reynolds-Smolensky index, calculated as $\overline{G B}-\overline{G A}$ (see text for details). Time-varying state characteristics are log real personal income per capita, the unemployment rate, the unionization rate, the sales tax rate, the maximum estate/inheritance tax rate, and an indicator for whether the state has an estate tax. Sample is restricted to inequality observations from 1983-2002. Sample size for all specifications is 1,020. 
tion of the population is $F(y)$ and the $p$ th quantile of income is $F^{-1}(p)$, the Lorenz Curve is

[3] $\quad L(p)=\frac{1}{\mu} \int_{0}^{F^{-1}(p)} y \cdot d F(y)$.

The S-Gini is, therefore, given by the formula

[4] $S G_{\delta}=1-\delta(\delta-1) \int_{0}^{1}(1-p)^{\delta-2} L(p) d(p)$.

A consistent estimator for the S-Gini, where $y_{1: n} \leq y_{2: n} \leq \ldots \leq y_{n: n}$ are the order statistics for income of $n$ individuals, is

[5] $S G_{\delta}=1-\frac{1}{\mu n^{\delta}} \sum_{i=1}^{n}\left((n-i+1)^{\delta}-(n-i)^{\delta}\right) y_{i: n}$,

where $\delta \leq 1$, the S-Gini is undefined. For $1<\delta<2$, the index places more weight on the top of the distribution, while for $\delta$ $>2$, the index places progressively more weight on the bottom of the distribution. When $\delta=2$, the S-Gini is identical to the Gini coefficient. For a more detailed discussion of the properties of the S-Gini, see Lambert (1993), Barrett and Donald (2002), and Zitikis and Gastwirth (2002).

Therefore it is straightforward to use the S-Gini to develop alternative measures of the redistributive effect of taxation, weighting the top and bottom of the distribution differently. In the second section, estimates were presented for a redistribution measure based on the Gini coefficient. Where $R_{\delta}$ is a redistribution measure based on the S-Gini:

[6] $R_{2}=\overline{S G B}_{2}-\overline{S G B}_{2}=\overline{G B}-\overline{G A}$.

Here, I present four alternative measures of redistributive effect; two that place more weight than the Gini-derived measure on the top of the income distribution:

[7] $R_{1.25}=\overline{S G B}_{1.25}-\overline{S G A}_{1.25}$;
[8] $R_{1.5}=\overline{S G B}_{1.5}-\overline{S G A}_{1.5}$.

And two that place more weight than the Gini-derived measure on the bottom of the income distribution:

[9] $R_{2.5}=\overline{S G B}_{2.5}-\overline{S G A}_{2.5}$;

$$
R_{3.5}=\overline{S G B}_{3.5}-\overline{S G A}_{3.5} .
$$

Summary statistics for each measure are presented in Appendix Table 1.

In each instance, I estimate the impact on the corresponding pre-tax S-Gini coefficient, with current redistribution and six lags of redistribution as the independent variables of interest. For example, in the case of the redistribution measure where $\delta=1.25$, I estimate the equation:

$$
\begin{aligned}
& S G B_{1.25, s t}=\alpha+\beta 1\left(\overline{S G B}_{1.25}-\overline{S G A}_{1.25}\right)_{s t} \\
& +\beta 2\left(\overline{S G B}_{1.25}-\overline{S G A}_{1.25}\right)_{s t-1}+\ldots \\
& +\beta 7\left(\overline{S G B}_{1.25}-\overline{S G A}_{1.25}\right)_{s t-6}+Z_{s t} \\
& +\zeta_{s}+\lambda_{t}+\varepsilon_{s t} .
\end{aligned}
$$

The interpretation of $\beta$ is, therefore, analogous to the second section. If $\beta=1$, then a tax system that has the mechanical effect of reducing the S-Gini ${ }_{\delta}$ leads to a behavioral change that increases the S-Gini ${ }_{\delta}$ by the same amount, while if $\beta=$ 0 , the redistributive effect of taxation, as measured by the change in the S-Gini ${ }_{\delta}$, has no impact on the distribution of gross wages.

Table 3 shows the results using the four alternative redistribution indices. While the effect of tax-induced redistribution on current wages appears to be slightly stronger at the top of the distribution, there is little difference between the four specifications. As with the Gini-derived redistribution measure $(\delta=2)$, the hypothesis that wage inequality does not rise in response to more redistributive taxes is not rejected in any specification. However, 
TABLE 3

HOW DO REDISTRIBUTIVE TAXES AFFECT THE TOP AND BOTTOM OF THE INCOME DISTRIBUTION?

\begin{tabular}{|c|c|c|c|c|}
\hline \multicolumn{5}{|c|}{ Dependent Variable: S-Gini Coefficient for Pre-Tax Hourly Wages } \\
\hline & $\begin{array}{l} \\
\delta=11] \\
\text { More } W \\
\text { Distribu }\end{array}$ & $\begin{array}{c}{[2]} \\
\delta=1.5 \\
\text { Top of } \\
\text { an Gini }\end{array}$ & $\begin{array}{c}{[3]} \\
\delta=2.5 \\
\text { More W } \\
\text { Distrib }\end{array}$ & $\begin{array}{l}\quad[4] \\
\qquad=3.5 \\
\text { Bottom of } \\
\text { an Gini }\end{array}$ \\
\hline Tax redistribution & $\begin{array}{l}-0.895 \\
{[1.024]}\end{array}$ & $\begin{array}{l}-0.672 \\
{[0.924]}\end{array}$ & $\begin{array}{c}-0.394 \\
{[0.820]}\end{array}$ & $\begin{array}{c}-0.57 \\
{[0.816]}\end{array}$ \\
\hline Tax redistribution ${ }_{t-1}$ & $\begin{array}{c}1.004 \\
{[0.838]}\end{array}$ & $\begin{array}{c}0.98 \\
{[0.816]}\end{array}$ & $\begin{array}{c}0.94 \\
{[0.897]}\end{array}$ & $\begin{array}{c}0.885 \\
{[1.017]}\end{array}$ \\
\hline Tax redistribution $_{t-2}$ & $\begin{array}{c}-0.556 \\
{[1.043]}\end{array}$ & $\begin{array}{l}-0.439 \\
{[0.981]}\end{array}$ & $\begin{array}{l}-0.223 \\
{[0.947]}\end{array}$ & $\begin{array}{c}-0.176 \\
{[1.026]}\end{array}$ \\
\hline Tax redistribution $_{t-3}$ & $\begin{array}{c}0.278 \\
{[0.984]}\end{array}$ & $\begin{array}{c}0.064 \\
{[0.941]}\end{array}$ & $\begin{array}{l}-0.306 \\
{[1.025]}\end{array}$ & $\begin{array}{c}-0.41 \\
{[1.215]}\end{array}$ \\
\hline Tax redistribution $_{t-4}$ & $\begin{array}{l}-1.000 \\
{[0.828]}\end{array}$ & $\begin{array}{l}-1.288 \\
{[0.779]}\end{array}$ & $\begin{array}{c}-1.843^{* *} \\
{[0.738]}\end{array}$ & $\begin{array}{c}-2.160^{* * *} \\
{[0.771]}\end{array}$ \\
\hline Tax redistribution $_{t-5}$ & $\begin{array}{c}0.251 \\
{[0.715]}\end{array}$ & $\begin{array}{c}0.27 \\
{[0.682]}\end{array}$ & $\begin{array}{c}0.281 \\
{[0.685]}\end{array}$ & $\begin{array}{c}0.345 \\
{[0.757]}\end{array}$ \\
\hline Tax redistribution ${ }_{t-6}$ & $\begin{array}{c}-0.821 \\
{[0.856]}\end{array}$ & $\begin{array}{l}-0.963 \\
{[0.839]}\end{array}$ & $\begin{array}{l}-1.013 \\
{[0.867]}\end{array}$ & $\begin{array}{c}-0.883 \\
{[0.953]}\end{array}$ \\
\hline $\begin{array}{l}\text { Time-varying state characteristics? } \\
\text { State and year fixed effects? } \\
\text { Region-specific time trend? } \\
\text { R-squared }\end{array}$ & $\begin{array}{l}\text { Yes } \\
\text { Yes } \\
\text { Yes } \\
0.65\end{array}$ & $\begin{array}{l}\text { Yes } \\
\text { Yes } \\
\text { Yes } \\
0.63\end{array}$ & $\begin{array}{l}\text { Yes } \\
\text { Yes } \\
\text { Yes } \\
0.61\end{array}$ & $\begin{array}{l}\text { Yes } \\
\text { Yes } \\
\text { Yes } \\
0.61\end{array}$ \\
\hline Sum of lagged redistribution coefficients & $\begin{array}{l}-0.845 \\
{[1.138]}\end{array}$ & $\begin{array}{l}-1.377 \\
{[1.113]}\end{array}$ & $\begin{array}{l}-2.165 \\
{[1.106]}\end{array}$ & $\begin{array}{l}-2.399 \\
{[1.131]}\end{array}$ \\
\hline Sum of all redistribution coefficients & $\begin{array}{l}-1.739 \\
{[0.980]}\end{array}$ & $\begin{array}{l}-2.049 \\
{[0.946]}\end{array}$ & $\begin{array}{l}-2.559 \\
{[0.901]}\end{array}$ & $\begin{array}{l}-2.969 \\
{[0.906]}\end{array}$ \\
\hline
\end{tabular}

One-Tailed F-test: H0 Is That Tax Redistribution Coefficients $\leq 0$

Can We Reject the Null That Pre-Tax Inequality Is Unaffected by...

\begin{tabular}{lllll} 
Current taxes? & No & No & No & No \\
The sum of lagged taxes? & No & No & No & No \\
The sum of current and lagged tax rates? & No & No & No & No \\
\hline
\end{tabular}

One-Tailed F-Test: H0 Is That Tax Redistribution Coefficients $\geq 1$

Can We Reject the Null That Pre-Tax Inequality Fully Adjusts in Response to...

$\begin{array}{lcccc}\text { Current taxes? } & \text { Yes } & \text { Yes } & \text { Yes } & \text { Yes } \\ & {[\mathrm{P}=0.03]} & {[\mathrm{P}=0.04]} & {[\mathrm{P}=0.05]} & {[\mathrm{P}=0.03]} \\ \text { The sum of lagged taxes? } & \text { Yes } & \text { Yes } & \text { Yes } & \text { Yes } \\ & {[\mathrm{P}=0.06]} & {[\mathrm{P}=0.02]} & {[\mathrm{P}<0.01]} & {[\mathrm{P}<0.01]} \\ \text { The sum of current and lagged tax rates? } & \text { Yes } & \text { Yes } & \text { Yes } & \text { Yes } \\ & {[\mathrm{P}<0.01]} & {[\mathrm{P}<0.01]} & {[\mathrm{P}<0.01]} & {[\mathrm{P}<0.01]}\end{array}$

Note: Robust standard errors, clustered at the state level, in brackets. ${ }^{*}, *$, and ${ }^{* * *}$ denote statistical significance at the $10 \%, 5 \%$, and $1 \%$ levels, respectively. "Tax Redistribution" is the negative of the Reynolds-Smolensky index, calculated as $\overline{S G B}_{\delta}-\overline{S G A}_{\delta}$ (see text for details). Time-varying state characteristics are log real personal income per capita, the unemployment rate, the unionization rate, the sales tax rate, the maximum estate/inheritance tax rate, and an indicator for whether the state has an estate tax. Sample is restricted to inequality observations from 1983-2002. Sample size for all specifications is 1,020. 
the null hypothesis that pre-tax inequality fully adjusts in response to taxes can be rejected in all 12 specifications. This provides evidence that states that impose a heavier tax burden on the rich do not see a sudden rise in top wage incomes, and similarly that states that impose a heavier tax burden on the poor do not see a sudden rise in wages towards the bottom of the distribution.

\section{MIGRATION, INCOME, AND POST- TAX INEQUALITY}

In the previous two sections, I found that the redistributive effect of state taxes had no significant impact on the pre-tax distribution of hourly wages. Here, I consider three other parts of the story: the impact of tax redistribution on mobility, post-tax inequality, and personal income.

First, does the redistributive effect of taxation tax drive interstate mobility? ${ }^{11}$ To test this, I use six measures of population mobility: the fraction of a state's adult population that moved in from another state during the year, the fraction of a state's population that has moved out to another state during the year, the ratio of in-movers' hourly wages to non-movers' wages, the ratio of outmovers' hourly wages to non-movers' wages, the change in the state's log population in that year, and the log of the state population. The first four variables are taken from the March CPS, so measures in year $t$ relate to migration not from January $t$ to December $t$, but from March $t$ until March $t+1 .^{12}$ Details of variable construction are provided in the Data Appendix.

As in earlier tables, all these specifications include state fixed effects, year fixed effects, and region-specific linear time trends. Note that state fixed effects have a different effect in columns 5 and 6 . In column 5 , the state fixed effect absorbs unobservable state-specific factors affecting the growth rate of a state's population, while in column 6 , the state fixed effect absorbs unobservable state-specific factors affecting the level of a state's population. Each of the specifications includes the current tax redistributivity variable, and six lags of tax redistributivity.

Recall that in Tables 1, 2, and 3, I estimated one-tailed F-tests, against the null hypotheses that the tax coefficients were $\leq 0$ or $\geq 1$. Here, I estimate standard twotailed F-tests, against the null hypothesis that taxes have no aggregate impact on interstate migration.

Overall, the results in Table 4 suggest that-in sum-tax changes do not impact interstate population flows, nor do they affect the relative wages of movers. Only three of the 18 F-tests are statistically significant: in the lagged specification, more redistributive taxes are associated with a fall in the relative wages of incoming migrants, and in the current and summed specifications, more redistributive taxes are associated with a smaller population. However, the relationship between population size and tax redistributivity becomes statistically insignificant when the model is specified with log population in differences (column 5) rather than levels (column 6). The association between

11 It is also plausible that the reverse is true: if for some exogenous reason a state's population becomes less mobile, then the state government, following the dictum of Mirrlees (1982) (that the optimal amount of redistribution by a state is a declining function of the degree of mobility in response to taxes), implements more redistributive taxes. This theory is not tested here.

12 One possible solution would be to convert the March $t$ to March $t+1$ data into January $t$ to December $t$ data by the simple formula: $X(\operatorname{Jan} t$ : Dec $t)=0.25 X(\operatorname{Mar} t-1$ : Mar $t)+0.75 X(\operatorname{Mar} t$ : Mar $t+1)$. Unfortunately, because mobility rates are missing for several years, this kind of averaging reduces the sample size too severely. 
TABLE 4

DOES TAX REDISTRIBUTION DRIVE INTERSTATE MIGRATION?

\begin{tabular}{|c|c|c|c|c|c|c|}
\hline Dependent Variable & $\begin{array}{c}\quad[1] \\
\text { Incoming } \\
\text { Migration } \\
\text { Rate }\end{array}$ & $\begin{array}{c}{[2]} \\
\text { Outgoing } \\
\text { Migration } \\
\text { Rate }\end{array}$ & $\begin{array}{c}\text { [3] } \\
\text { Wage Ratio: } \\
\text { Incoming/ } \\
\text { Nonmovers }\end{array}$ & $\begin{array}{c}{[4]} \\
\text { Wage Ratio: } \\
\text { Outgoing/ } \\
\text { Nonmovers }\end{array}$ & $\begin{array}{c}{[5]} \\
\text { Population } \\
\text { Growth } \\
\text { Rate }\end{array}$ & $\begin{array}{c}6] \\
\text { Log } \\
\text { Population }\end{array}$ \\
\hline$\overline{\mathrm{TR}_{t}}$ & $\begin{array}{l}-0.670 \\
{[0.650]}\end{array}$ & $\begin{array}{l}-0.369 \\
{[0.864]}\end{array}$ & $\begin{array}{c}17.251 \\
{[11.760]}\end{array}$ & $\begin{array}{c}-18.84 \\
{[24.131]}\end{array}$ & $\begin{array}{l}-0.704 \\
{[0.526]}\end{array}$ & $\begin{array}{c}-6.479 * * \\
{[3.078]}\end{array}$ \\
\hline $\mathrm{TR}_{t-1}$ & $\begin{array}{c}1.063 \\
{[1.301]}\end{array}$ & $\begin{array}{l}-1.258 \\
{[0.884]}\end{array}$ & $\begin{array}{c}-29.954^{*} \\
{[15.078]}\end{array}$ & $\begin{array}{l}63.088^{* *} \\
{[25.599]}\end{array}$ & $\begin{array}{c}0.597 \\
{[0.501]}\end{array}$ & $\begin{array}{l}-4.375 \\
{[2.723]}\end{array}$ \\
\hline $\mathrm{TR}_{t-2}$ & $\begin{array}{c}-0.91 \\
{[1.267]}\end{array}$ & $\begin{array}{c}-0.603 \\
{[0.821]}\end{array}$ & $\begin{array}{c}16.575 \\
{[19.557]}\end{array}$ & $\begin{array}{l}-21.978 \\
{[20.474]}\end{array}$ & $\begin{array}{l}-1.202 \\
{[0.760]}\end{array}$ & $\begin{array}{l}-1.345 \\
{[1.505]}\end{array}$ \\
\hline $\mathrm{TR}_{t-3}$ & $\begin{array}{l}-0.309 \\
{[1.128]}\end{array}$ & $\begin{array}{c}0.45 \\
{[0.973]}\end{array}$ & $\begin{array}{c}-8.149 \\
{[19.264]}\end{array}$ & $\begin{array}{c}11.423 \\
{[21.365]}\end{array}$ & $\begin{array}{c}0.717 \\
{[0.793]}\end{array}$ & $\begin{array}{l}-1.824 \\
{[1.506]}\end{array}$ \\
\hline $\mathrm{TR}_{t-4}$ & $\begin{array}{l}-0.884 \\
{[1.008]}\end{array}$ & $\begin{array}{c}0.055 \\
{[1.088]}\end{array}$ & $\begin{array}{c}6.558 \\
{[15.297]}\end{array}$ & $\begin{array}{c}-9.134 \\
{[22.947]}\end{array}$ & $\begin{array}{c}-0.012 \\
{[1.002]}\end{array}$ & $\begin{array}{c}1.862 \\
{[1.774]}\end{array}$ \\
\hline $\mathrm{TR}_{t-5}$ & $\begin{array}{l}1.965^{*} \\
{[1.101]}\end{array}$ & $\begin{array}{c}0.351 \\
{[0.883]}\end{array}$ & $\begin{array}{c}-12.26 \\
{[12.736]}\end{array}$ & $\begin{array}{c}10.183 \\
{[25.651]}\end{array}$ & $\begin{array}{c}0.487 \\
{[0.894]}\end{array}$ & $\begin{array}{l}-2.683 \\
{[1.625]}\end{array}$ \\
\hline $\mathrm{TR}_{t-6}$ & $\begin{array}{l}-1.269 \\
{[0.851]}\end{array}$ & $\begin{array}{c}0.487 \\
{[0.757]}\end{array}$ & $\begin{array}{c}4.095 \\
{[11.551]}\end{array}$ & $\begin{array}{c}-40.293^{*} \\
{[23.171]}\end{array}$ & $\begin{array}{c}0.107 \\
{[0.583]}\end{array}$ & $\begin{array}{l}-0.983 \\
{[3.506]}\end{array}$ \\
\hline $\begin{array}{l}\text { Time-varying state characteristics? } \\
\text { State and year fixed effects (FE)? } \\
\text { Region-specific time trend? } \\
\text { Observations } \\
\text { R-squared }\end{array}$ & $\begin{array}{l}\text { Yes } \\
\text { Yes } \\
\text { Yes } \\
918 \\
0.73\end{array}$ & $\begin{array}{l}\text { Yes } \\
\text { Yes } \\
\text { Yes } \\
918 \\
0.73\end{array}$ & $\begin{array}{l}\text { Yes } \\
\text { Yes } \\
\text { Yes } \\
918 \\
0.15\end{array}$ & $\begin{array}{l}\text { Yes } \\
\text { Yes } \\
\text { Yes } \\
917 \\
0.13\end{array}$ & $\begin{array}{c}\text { Yes } \\
\text { Yes } \\
\text { Yes } \\
1,020 \\
0.64\end{array}$ & $\begin{array}{c}\text { Yes } \\
\text { Yes } \\
\text { Yes } \\
1,020 \\
0.99\end{array}$ \\
\hline Sum of lagged TR coefficients & $\begin{array}{l}-0.344 \\
{[0.910]}\end{array}$ & $\begin{array}{l}-0.518 \\
{[1.218]}\end{array}$ & $\begin{array}{l}-23.135 \\
{[11.457]}\end{array}$ & $\begin{array}{c}13.288 \\
{[23.724]}\end{array}$ & $\begin{array}{c}0.694 \\
{[0.766]}\end{array}$ & $\begin{array}{l}-9.350 \\
{[6.480]}\end{array}$ \\
\hline Sum of all TR coefficients & $\begin{array}{l}-1.014 \\
{[0.806]}\end{array}$ & $\begin{array}{l}-0.887 \\
{[1.157]}\end{array}$ & $\begin{array}{c}-5.883 \\
{[11.283]}\end{array}$ & $\begin{array}{c}-5.552 \\
{[17.104]}\end{array}$ & $\begin{array}{l}-0.010 \\
{[0.590]}\end{array}$ & $\begin{array}{r}-15.829 \\
{[6.434]}\end{array}$ \\
\hline \multicolumn{7}{|c|}{$\begin{array}{l}\text { Two-Tailed F-Test: H0 Is That Tax Redistribution Coefficients }=0 \\
\text { Can We Reject the Null That the Dependent Variable Is Unaffected by... }\end{array}$} \\
\hline Current taxes? & No & No & No & No & No & $\begin{array}{c}\text { Yes } \\
{[\mathrm{P}=0.04]}\end{array}$ \\
\hline The sum of lagged taxes? & No & No & $\begin{array}{c}\text { Yes } \\
{[\mathrm{P}=0.05]}\end{array}$ & No & No & No \\
\hline The sum of current and lagged tax rates? & ? No & No & No & No & No & $\begin{array}{c}\text { Yes } \\
{[\mathrm{P}=0.02]}\end{array}$ \\
\hline
\end{tabular}

Note: Robust standard errors, clustered at the state level, in brackets. ${ }^{*}{ }^{* *}$, and ${ }^{* * *}$ denote statistical significance at the $10 \%, 5 \%$, and $1 \%$, levels, respectively. "TR" is the negative of the Reynolds-Smolensky index, calculated as $\overline{G B}-\overline{G A}$ (see text for details). The population growth rate (column 5 ) is the change in $\log$ population from year $t-1$ to year $t$. Time-varying state characteristics are log real personal income per capita, the unemployment rate, the unionization rate, the sales tax rate, the maximum estate/inheritance tax rate, and an indicator for whether the state has an estate tax. Dependent variables in columns 1 to 4 are measured from March $_{t}$ to March $_{t+1}$. 
population and taxes is, therefore, fragile at best. ${ }^{13}$

I now turn to the question of how redistributive taxes affect income and the post-tax distribution of income. This question is particularly pertinent in the light of Feldstein and Wrobel's (1998, p. 392) conclusion:

"[T]here can be no trade-off at the state level between distribution goals and economic efficiency. Shifts in state tax progressivity, by altering the structure of employment in the state and distorting the mix of labor inputs used by firms in the state, create deadweight efficiency losses without achieving any net local redistribution of real incomes."

Using a similar empirical approach to that used to analyze migration, it is possible to directly test the impact of more redistributive state taxation systems have on post-tax inequality and mean percapita income. Post-tax inequality is measured from the same March CPS surveys as were used to calculate pre-tax inequality. However, in this case, annual earnings and family characteristics are first used to calculate each individual's average tax rate (ATR), and the pre-tax hourly wage is then multiplied by $\{1-\mathrm{ATR}\}$ to arrive at a post-tax hourly wage. Within each state,
I then calculate the distribution of these post-tax hourly wages. Figure 5 shows the post-tax Ginis, which have a mean of 0.33 and a standard deviation of 0.015 . As a measure of personal income, I use the log of real state personal income per capita. In both cases, I estimate two-tailed F-tests against the null that tax redistribution has no impact on the dependent variable.

With regard to the distribution of post-tax hourly wages, the results from column 1 of Table 5 suggest that more redistributive taxes do (with some lag) lead to a more equal distribution of income. From years $t-6$ to $t$, a tax system that mechanically reduces wage inequality by one standard deviation (0.3 Gini points) leads to a 0.8 point drop $(0.003 \times$ -2.5) in the post-tax Gini, an effect that is statistically significant at the one percent level.

As to the potential efficiency cost of more redistributive taxes, the results in column 2 do not support the theory that more redistributive taxes harm a state's economy. Indeed, more redistributive taxes appear to be associated with slightly more rapid economic growth. A tax system that is one standard deviation more redistributive is associated with a four percent increase $(0.003 \times 14.6)$ in the growth rate over the years $t-6$ to $t$, an effect that is statistically significant at the five percent level. ${ }^{14}$

\footnotetext{
13 An alternative approach to estimating F-tests on the sum of the tax coefficients is to estimate joint F-tests against the null hypothesis that all of the tax redistribution coefficients are equal to zero. These reject the null in column 4, where the dependent variable is the ratio of out-movers' hourly wages to non-movers' wages $(\mathrm{F}=2.66, \mathrm{P}=0.02)$. This result is driven by the first lag, which has a positive coefficient; suggesting that more redistributive taxes are associated with high-wage outmigration after one year (though as the summed coefficients show, they have no aggregate impact over a seven-year period). A joint F-test also rejects the hypothesis that all of the tax redistribution coefficients are equal to zero in column 6 , where the dependent variable is $\log$ population $(\mathrm{F}=1.93, \mathrm{P}=0.08)$. In this case, the largest $\mathrm{t}$-statistic is on the current tax redistributivity variable, which has a negative coefficient, suggesting that more redistributive state taxes are associated with a smaller population (though as the insignificant results in column 5 show, this result is not robust to specifying the dependent variable in differences instead of levels).

14 The empirical literature on state taxes and economic growth has tended not to focus on redistributivity, but on average or marginal tax rates. The results from these studies are mixed: for recent reviews of the evidence, see Holcombe and Lacombe (2004) and Bania, Gray, and Stone (2007).
} 
Figure 5. Post-Tax Hourly Wage Inequality by State 1977-2002

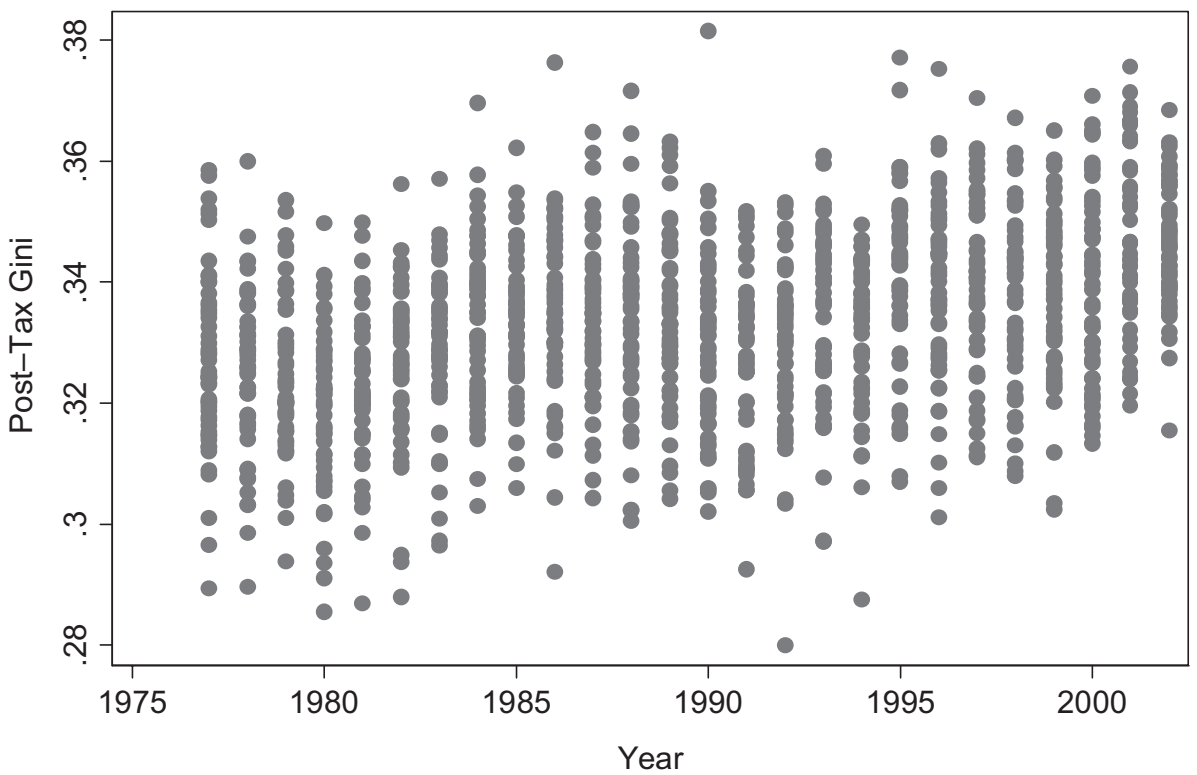

Source: Author's calculations, from March Current Population Surveys and Taxsim model.

\section{THE POLITICAL ECONOMY OF TAXATION AND INEQUALITY}

Until this point, I have assumed that taxes drive inequality. But might the reverse be true? Discussing the conclusions of Feldstein and Wrobel (1998), Bakija and Slemrod (2004, p. 56, n5) argue that observing a positive relationship between tax redistribution and inequality of gross hourly wages would also be consistent with a "stabilizing" political economy explanation, under which states with more unequal wage distributions implement more redistributive taxation systems.

It is also possible that politics operates in the opposite direction, and that states with more equal wage distributions tend to implement more redistributive taxation systems. One reason that this might occur is if the average value of public goods to members of a community increases as heterogeneity decreases (as suggested by Alesina, Baqir, and Easterly, 1999). Another possibility is that if the rich experience an increase in their incomes, they may channel part of this into campaign contributions to candidates who prefer less redistributive taxation.

One way of testing these two theories is to estimate almost the reverse regression to that presented in equation [2]. Instead of looking at the effect of current and lagged taxes on inequality, I now explore whether lagged inequality appears to have any aggregate impact on tax redistribution. Of course, it is not possible to test whether inequality in the current period affects tax redistribution in the current period. But inherent in the political economy explanations is some notion of a lag, so this test should be fairly robust. ${ }^{15}$

15 In a cross-sectional analysis, Chernick (2005) finds that greater inequality in a state's pre-tax income distribution is slightly offset by more progressive tax systems. 
TABLE 5

HOW DO REDISTRIBUTIVE TAXES AFFECT POST-TAX INEQUALITY AND AVERAGE INCOME?

\begin{tabular}{|c|c|c|}
\hline Dependent Variable & $\begin{array}{c}{[1]} \\
\text { Post-Tax Gini for } \\
\text { Hourly Wages }\end{array}$ & $\begin{array}{c}{[2]} \\
\text { Log Real Personal Income } \\
\text { Per Capita }\end{array}$ \\
\hline Tax redistribution $_{t}$ & $\begin{array}{c}-0.439 \\
{[0.870]}\end{array}$ & $\begin{array}{c}1.328 \\
{[2.404]}\end{array}$ \\
\hline Tax redistribution $_{t-1}$ & $\begin{array}{c}0.778 \\
{[0.830]}\end{array}$ & $\begin{array}{c}3.481 \\
{[2.368]}\end{array}$ \\
\hline Tax redistribution $_{t-2}$ & $\begin{array}{l}-0.357 \\
{[0.868]}\end{array}$ & $\begin{array}{l}2.094^{*} \\
{[1.243]}\end{array}$ \\
\hline Tax redistribution $_{t-3}$ & $\begin{array}{c}-0.07 \\
{[0.914]}\end{array}$ & $\begin{array}{l}2.625^{* *} \\
{[1.168]}\end{array}$ \\
\hline Tax redistribution $_{t-4}$ & $\begin{array}{c}-1.613^{* *} \\
{[0.710]}\end{array}$ & $\begin{array}{c}-2.384 \\
{[2.363]}\end{array}$ \\
\hline Tax redistribution $_{t-5}$ & $\begin{array}{c}0.392 \\
{[0.631]}\end{array}$ & $\begin{array}{c}2.488 \\
{[1.903]}\end{array}$ \\
\hline Tax redistribution $_{t-6}$ & $\begin{array}{c}-1.21 \\
{[0.798]}\end{array}$ & $\begin{array}{c}4.998 \\
{[3.748]}\end{array}$ \\
\hline $\begin{array}{l}\text { Time-varying state characteristics? } \\
\text { State and year fixed effects? } \\
\text { Region-specific time trend? } \\
\text { Observations } \\
\text { R-squared }\end{array}$ & $\begin{array}{c}\text { Yes } \\
\text { Yes } \\
\text { Yes } \\
1,020 \\
0.51\end{array}$ & $\begin{array}{l}\text { Yes } \\
\text { Yes } \\
\text { Yes } \\
1,020 \\
0.99\end{array}$ \\
\hline Sum of lagged redistribution coefficients & $\begin{array}{l}-2.080 \\
{[1.042]}\end{array}$ & $\begin{array}{c}13.303 \\
{[5.146]}\end{array}$ \\
\hline Sum of all redistribution coefficients & $\begin{array}{l}-2.518 \\
{[0.839]}\end{array}$ & $\begin{array}{l}14.631 \\
{[6.056]}\end{array}$ \\
\hline
\end{tabular}

Two-Tailed F-Test: H0 Is That Tax Redistribution Coefficients $=0$

Can We Reject the Null That the Dependent Variable Is Unaffected by...
Current taxes?
No
No
The sum of lagged taxes?
Yes
$[\mathrm{P}=0.05]$
Yes
$[\mathrm{P}=0.01]$
The sum of current and lagged tax rates?
Yes
Yes
$[\mathrm{P}<0.01]$
$[\mathrm{P}=0.02]$

Note: Robust standard errors, clustered at the state level, in brackets. ${ }^{*},{ }^{* *}$, and ${ }^{* * *}$ denote statistical significance at the $10 \%, 5 \%$, and $1 \%$ levels, respectively. "Tax Redistribution" is the negative of the Reynolds-Smolensky index, calculated as $\overline{G B}-\overline{G A}$ (see text for details). Time-varying state characteristics in column 1 are log real personal income per capita, the unemployment rate, the unionization rate, the sales tax rate, the maximum estate/inheritance tax rate, and an indicator for whether the state has an estate tax. In column 2, the same set of time-varying state characteristics are included, with the exception of log real personal income per capita. 
TABLE 6

POLITICAL ECONOMY—DOES INEQUALITY DRIVE TAX REDISTRIBUTION?

\begin{tabular}{|c|c|c|c|}
\hline \multicolumn{4}{|l|}{ Dependent Variable: Tax Redistribution Index } \\
\hline & [1] & [2] & [3] \\
\hline$\overline{\text { Pre-tax Gini }}{ }_{t-1}$ & $\begin{array}{c}-0.002 \\
{[0.002]}\end{array}$ & $\begin{array}{c}-0.002 \\
{[0.002]}\end{array}$ & $\begin{array}{c}-0.003 \\
{[0.002]}\end{array}$ \\
\hline Pre-tax Gini ${ }_{t-2}$ & $\begin{array}{c}0.002 \\
{[0.002]}\end{array}$ & $\begin{array}{c}0.001 \\
{[0.002]}\end{array}$ & $\begin{array}{c}0.000 \\
{[0.002]}\end{array}$ \\
\hline Pre-tax Gini $i_{t-3}$ & & $\begin{array}{c}0.001 \\
{[0.002]}\end{array}$ & $\begin{array}{c}0.001 \\
{[0.002]}\end{array}$ \\
\hline Pre-tax Gini $t_{t-4}$ & & $\begin{array}{c}0.004^{*} \\
{[0.002]}\end{array}$ & $\begin{array}{c}0.004^{*} \\
{[0.002]}\end{array}$ \\
\hline Pre-tax Gini ${ }_{t-5}$ & & & $\begin{array}{c}0.003 \\
{[0.002]}\end{array}$ \\
\hline Pre-tax Gini ${ }_{t-6}$ & & & $\begin{array}{l}0.006^{* *} \\
{[0.003]}\end{array}$ \\
\hline Time-varying state characteristics? & Yes & Yes & Yes \\
\hline State and year fixed effects? & Yes & Yes & Yes \\
\hline Region-specific time trend? & Yes & Yes & Yes \\
\hline Observations & 1,020 & 1,020 & 1,020 \\
\hline R-squared & 0.94 & 0.94 & 0.94 \\
\hline Sum of lagged Gini coefficients & $\begin{array}{c}0.000 \\
{[0.003]}\end{array}$ & $\begin{array}{c}0.004 \\
{[0.007]}\end{array}$ & $\begin{array}{c}0.011 \\
{[0.009]}\end{array}$ \\
\hline $\begin{array}{l}\text { Two-Tailed F-Test: H0 Is That Gini Coefficients =0 } \\
\text { Can We Reject the Null That the Dependent Variable Is } \\
\text { Unaffected by the Sum of Lagged Inequality Coefficients? }\end{array}$ & No & No & No \\
\hline
\end{tabular}

Note: Robust standard errors, clustered at the state level, in brackets. ${ }^{*},{ }^{* *}$, and ${ }^{* * *}$ denote statistical significance at the $10 \%, 5 \%$, and $1 \%$ levels, respectively. "Tax Redistribution index" is the negative of the Reynolds-Smolensky index, calculated as $\overline{G B}-\overline{G A}$ (see text for details). Time-varying state characteristics are log real personal income per capita, the unemployment rate, the unionization rate, the sales tax rate, the maximum estate/inheritance tax rate, and an indicator for whether the state has an estate tax.

Table 6 indicates little evidence of a relationship between inequality and the tax structure that states choose. Although the linear sum of the inequality coefficients is positive in the second and third columns (consistent with Bakija and Slemrod's critique of the findings of Feldstein and Wrobel), it is not statistically significant at conventional levels. As a result, the claim that policymakers opt for redistributive taxes as a brake on rising wage inequality remains merely suggestive.

\section{CONCLUSION}

This paper has sought to estimate the extent to which interstate migration thwarts attempts by states to reduce inequality via more redistributive taxes. Using a Gini-based index of tax redistribution for U.S. states over the period 1977-2002, I find little evidence that-in aggregate-more redistributive state taxes lead to a more unequal distribution of pre-tax hourly wages. This remains true when alternative measures of redistribution are used, placing more weight on the bottom or on the top of the distribution. Evidence from population flows helps corroborate this: overall, more redistributive state taxes do not appear to have a substantial impact on the composition or volume of interstate migration.

Given that the pre-tax wages distribution does not adjust to offset the effect of redistributive taxes, it should be 
unsurprising that more redistributive taxation is associated with a more equal distribution of post-tax hourly wages. Regarding the efficiency cost of taxation, I find no evidence that states with more redistributive taxes experience slower growth in per capita personal income. (If anything, states with redistributive taxes grow faster.) Looking at the effect of inequality on redistribution, I find that past inequality is positively associated with more redistributive taxes in the current period, though the effect is not statistically significant.

While this paper presents evidence that migration does not undo the effects of redistributive taxes at a state level, it nonetheless seems plausible that at a sufficiently small geographic level, this effect will occur. For example, it may be that at a city level, redistributive taxes are unable to affect the post-tax distribution of income.

\section{Acknowledgments}

I am grateful to Garry Barrett, Howard Chernick, John Creedy, Russell Hillberry, Therese McGuire, Francesc Ortega, Sher Verick, two anonymous referees, and seminar participants at the ANU/IZA Social Policy Evaluation Annual Conference, the Public Policy Institute of California, the University of Melbourne, and the University of New South Wales for comments on earlier drafts, to Stephen Jenkins for assistance in applying his ineqdeco Stata routine, and in particular to Daniel Feenberg for many suggestions and valuable discussions on this topic.

\section{REFERENCES}

Alesina, Alberto, Reza Baqir, and William

Easterly.

"Public Goods and Ethnic Divisions." Quarterly Journal of Economics 114 No. 4 (November, 1999): 1243-84.
Autor, David H., Lawrence F. Katz, and Melissa S. Kearney.

"Trends in U.S. Wage Inequality: Re-Assessing the Revisionists." Review of Economics and Statistics 90 No. 2 (forthcoming).

Bakija, Jon, and Joel Slemrod.

"Do the Rich Flee from High State Taxes? Evidence from Federal Estate Tax Returns."

NBER Working Paper No. 10645. Cambridge, MA: National Bureau of Economic Research, 2004.

Bania, Neil, Jo Anna Gray, and Joe A. Stone.

"Growth, Taxes, and Government Expenditures: Growth Hills for U.S. States." National Tax Journal 60 No. 2 (June, 2007): 193-204.

Barrett, Garry F., and Stephen G. Donald.

"Statistical Inference with Generalized Gini Indices of Inequality and Poverty." Discussion Paper No. 2002/01, School of Economics, University of New South Wales. 2002.

Bertrand, Marianne, Esther Duflo, and Sendhil Mullainathan.

"How Much Should We Trust Differences-in-Differences Estimates?" Quarterly Journal of Economics 119 No. 1 (February, 2004): 249-75.

Blanchard, Olivier J., and Lawrence F. Katz.

"Regional Evolutions." Brookings Papers on

Economic Activity No. 1 (1992): 1-76.

Census Bureau.

"Census Questionnaire Content, 1990 CQC-12." Washington, D.C.: U.S. Census Bureau, 1994.

Chernick, Howard.

"On the Determinants of Subnational Tax Progressivity in the U.S." National Tax Journal 58 No. 1 (March, 2005): 93-112.

Creedy, John.

"Taxation, Redistribution and Progressivity: An Introduction." Australian Economic Review 32 No. 4 (December, 1999): 410-22.

Cushing-Daniels, Brendan.

"Migration in the US: What Role Welfare?" Gettysburg College, PA. Mimeo, 2004.

Donaldson, David, and John A. Weymark. "A Single Parameter Generalization of the Gini Indices for Inequality." Journal of Economic Theory 22 No. 1 (February, 1980): 67-86. 
Feenberg, Daniel, and Elisabeth Coutts. "An Introduction to the TAXSIM Model." Journal of Policy Analysis and Management 12 No. 1 (Winter, 1993): 189-94.

Feldstein, Martin, and Marian V. Wrobel. "Can State Taxes Redistribute Income?" Journal of Public Economics 68 No. 3 (June, 1998): 369-96.

Hirsch, Barry T., David A. Macpherson, and Wayne G. Vroman.

"Estimates of Union Density by State." Monthly Labor Review 124 No. 7 (July, 2001): 51-5.

Holcombe, Randall G., and Donald J. Lacombe. "The Effect of State Income Taxation on Per Capita Income Growth." Public Finance Review 32 No. 3 (May, 2004): 292-312.

Houtenville, Andrew J., and Karen S. Conway. "Elderly Migration and State Fiscal Policy: Evidence from the 1990 Census Migration Flows." National Tax Journal 54 No. 1 (March, 2001): 103-23.

Lambert, Peter J.

The Distribution and Redistribution of Income: A Mathematical Analysis, 2nd edition. Manchester, UK: Manchester University Press, 1993.

Leigh, Andrew.

"Who Benefits from the Earned Income Tax Credit? Incidence Among Recipients, Coworkers and Firms." Australian National University CEPR Discussion Paper No. 494. Canberra: Australian National University, 2004.

Mirrlees, James A.

"Migration and Optimal Income Taxes." Journal of Public Economics 18 No. 3 (August, 1982): 319-41.

Musgrave, Richard.

The Theory of Public Finance. New York: McGraw-Hill, 1959.

Oates, Wallace E.

Fiscal Federalism. New York: Harcourt Brace Jovanovich, 1972.

Reed, Deborah, Melissa G. Haber, and Laura Mameesh.

The Distribution of Income in California. San Francisco, CA: Public Policy Institute of California, 1996.
Reynolds, Morgan, and Eugene Smolensky. Public Expenditure, Taxes and the Distribution of Income. New York: Academic Press, 1977.

Schaffer, Mark E., and Steven Stillman. "xtoverid: Stata module to calculate tests of overidentifying restrictions after xtreg, xtivreg, xtivreg2 and xthtaylor." http:// ideas.repec.org/c/boc/bocode/s456779. html, 2006. Accessed February 14, 2008.

Zitikis, Ričardas, and Joseph L. Gastwirth. "The Asymptotic distribution of the S-Gini Index." Australian and New Zealand Journal of Statistics 44 No. 4 (December, 2002): 439-46.

\section{DATA APPENDIX}

\section{Inequality}

Inequality measures are calculated from the March CPS, using Stephen Jenkins' "ineqdeco" Stata routine. Person-weights were used, and hourly wages were not adjusted for family size. Since the CPS asks households about earnings in the previous year, the surveys from March 1978 to March 2003 provide data on household income in the years 1977-2002. The sample is further restricted to adults aged 16-55 with positive hours and earnings. Hourly wages are calculated by dividing annual earnings for the previous year by the total number of hours worked in the previous year (calculated by multiplying the number of weeks worked in the previous year by the usual number of hours worked per week in the previous year).

To avoid extreme values biasing the calculations, hourly wages below a minimum value are omitted and those above an upper threshold are truncated. In 2002, the minimum value was one dollar and the top-code was $\$ 500$. In earlier years, these numbers are indexed to changes in average wages. For example in 1977, observations with hourly wages below $\$ 0.27$ were dropped, while the top code was set at \$134.11 per hour.

Since I calculate hourly wages as annual earnings divided by the total number of hours worked in the previous year, the number of 
hourly wage observations that are top coded in each year is affected by the top coding of annual earnings in the CPS. In income years $1977-1980$, this is set at $\$ 50,000$, in 1981-1983 at $\$ 75,000$, and in 1984-1994 at $\$ 99,999$. From 1995-2002, top coded values were given the mean value for all top coded observations (e.g., in 1995, all those who earned $\$ 150,000$ or more were assigned earnings of $\$ 576,372$ ). This change does not appear to have had a major impact on the number of hourly wage observations that I top coded, which ranged from 8-40 in income years 1977-1994, and from $27-58$ in income years $1995-2002$. The number of top coded hourly wage observations was 40 in 1994, and 48 in 1995.

Although the CPS is designed to be representative at a state level, the person-weights that are provided are calculated based on national demographics, rather than state demographics. However, this is unlikely to make a substantial difference. Using the CPS to calculate trends in inequality in California, a state whose demographic composition is very different to the nation as a whole, Reed, Haber, and Mameesh (1996, Appendix B) used census data to form new CPS weights for California, and found that it made virtually no difference to their estimates.

\section{Tax Redistribution}

To calculate redistribution measures, I use a national sample comprising a randomly selected ten percent of the March 1990 CPS (15,847 individuals). Income is indexed by multiplying each family's income by $\left(\right.$ MedEarn $_{s t} /$ MedEarn $_{1990}$ ), where MedEarn ${ }_{s t}$ is median family income in a given state and year, and MedEarn $_{1990}$ is the median family income across the United States in $1990(\$ 38,640)$. This ensures that the distribution of earnings remains unchanged, but that incomes are at an appropriate level for the tax brackets in a given state and year.

For example, median family earnings in North Dakota in 1984 were $\$ 23,491$, so in order to calculate tax redistribution, I take the 15,847 individuals from in the 1990 CPS sample, multiply their incomes by $0.607(\$ 23,491 / \$ 38,640)$, then assign them the state code for North Dakota, and the year 1984.

Each state-year sample is then fed through the National Bureau of Economic Research's Taxsim program (Feenberg and Coutts, 1993), version 5.1. To simplify calculations, I assume that all family income is wage income, that individuals file as singles, and couples file jointly (with two-thirds of the income assigned to the primary earner). Dependent child exemptions and age exemptions are taken into account. Post-tax income is net of state and federal taxes, but not net of FICA, which is regarded as akin to savings. Taxsim covers all 50 states plus the District of Columbia from 1977-2002. Therefore I feed the same sample (with incomes indexed according to the median income in that state and year) through the Taxsim program a total of 1,326 times $(51 \times 26)$. The ratio of post-tax income to pre-tax income gives ( 1 - ATR).

To calculate a measure of tax redistribution as it applies to hourly wages, I calculate pre-tax hourly earnings in the same manner as for the state inequality statistics, i.e., by dividing annual earnings for the previous year by the total number of hours worked in the previous year. As with the inequality measures, the sample is restricted to those aged 16-55, and the same bottom-coding and top-coding rules are applied to pre-tax hourly earnings. The pre-tax Gini coefficient for all states and years remains constant at 0.36 , while the pre-tax S-Ginis are $0.15(\delta=1.25), 0.24(\delta=1.5), 0.43(\delta=2.5)$, and $0.52(\delta=3.5)$. Post-tax hourly earnings are then calculated by multiplying pre-tax earnings by ( 1 - ATR). The difference between the Gini (S-Gini) of pre-tax hourly earnings and the corresponding Gini (S-Gini) for post-tax hourly earnings is the measure of tax redistribution in a given state and year.

\section{Other State Variables}

Migration rates and hourly wages are calculated from March CPS data, applying the same sample restrictions as used in calculating the inequality measures (sample restricted to adults aged 16-55, hourly wages bottom and top-coded). Since the mobility question was only asked for the income years 1981-1984, 
1986-1994, and 1996-2002, the sample for this specification is somewhat smaller. The migration question asks about mobility since March 1 in the previous year, and thus does not match up perfectly with the calendar year measures used for other statistics. For example, I match migration data from March 2002 to March 2003 with tax redistribution in tax year 2002. Note that the outgoing migration rate is smaller than the incoming migration rate, because some CPS respondents identify as interstate movers, but fail to identify the state from which they moved.

Real personal income and population are from the Bureau of Economic Analysis (http:/ / www.bea.gov/bea/regional/).

Unemployment rates are from the Bureau of Labor Statistics (http://data.bls.gov/).

Unionization rate is the percentage of each state's nonagricultural wage and salary employees who are union members. Estimates are based on the 1983-2002 CPS Outgoing Rotation Group (ORG) earnings files, the 1973-1981 May CPS earnings files, and the BLS publication, Directory of National Unions and Employee Associations, for various years. Details on data and methodology are provided in Hirsch, Macpherson, and Vroman (2001) (accompanying data online at http://www. unionstats.com/).

State sales taxes, state inheritance taxes, and state estate taxes are from the World Tax Database (http:/ /www.bus.umich.edu/otpr/), downloaded December 10, 2007. Sales tax rates ignore exemptions (e.g., for food or prescription drugs). I combine state inheritance taxes and estate taxes into a single variable (no state has both), and also include a dummy variable to account for the possibility that the two types of taxes have different impacts.

Summary statistics for all variables are provided in Appendix Table 1.

APPENDIX TABLE 1

SUMMARY STATISTICS

\begin{tabular}{lccc}
\hline Variable & Mean & SD & N \\
\hline Current Period Variables (1983-2002) & & & 1,020 \\
Pre-Tax Gini & 0.358 & 0.018 & 1,020 \\
Post-Tax Gini & 0.335 & 0.015 & 1,020 \\
S-Gini $(\delta=1.25)$ & 0.144 & 0.010 & 1,020 \\
S-Gini $(\delta=1.5)$ & 0.239 & 0.015 & 1,020 \\
S-Gini $(\delta=2.5)$ & 0.432 & 0.019 & 1,020 \\
S-Gini $(\delta=3.5)$ & 0.522 & 0.020 & 918 \\
Incoming migration rate (from interstate) & 0.048 & 0.019 & 918 \\
Outgoing migration rate (to another state) & 0.036 & 0.019 & 918 \\
Wage ratio: incoming/nonmovers & 0.968 & 0.194 & 1,020 \\
Wage ratio: outgoing/nonmovers & 0.980 & 0.310 & 1,020 \\
Log population (non-institutional) & 14.657 & 1,020 \\
Sales tax rate & 0.045 & 0.018 & 1,020 \\
Maximum state inheritance/estate tax rate & 0.032 & 0.051 & 1,020 \\
Indicator for state estate tax & 0.100 & 0.300 & 1,020 \\
Unemployment rate & 0.058 & 0.020 & 1,020 \\
Log real state personal income per capita & 9.894 & 0.307 & \\
Unionization rate & 0.146 & 0.062 & 1,326 \\
& & & 1,326 \\
Current and Lagged Variables (1977-2002) & & & 1,326 \\
Redistribution (Gini) & 0.025 & 0.003 & 1,326 \\
Redistribution (S-Gini $\delta=1.25)$ & 0.012 & 0.002 & 1,326 \\
Redistribution (S-Gini $\delta=1.5)$ & 0.018 & 0.002 & 0.003 \\
Redistribution (S-Gini $\delta=2.5$ ) & 0.027 & 0.003 & \\
Redistribution (S-Gini $\delta=3.5$ ) & 0.027 & & \\
\hline
\end{tabular}

Note: All specifications are restricted to dependent variables that are measured over the period 1983-2002. The maximum number of lags of the tax rate variables is six, so summary statistics for tax rates cover the years 1977-2002. 
Reproduced with permission of the copyright owner. Further reproduction prohibited without permission. 